\title{
Accreditation of Interpreter Training Courses Curriculum in Bachelors of English Translation in Iranian Universities
}

\author{
Azizollah Dabaghi (Corresponding author) \\ Department of English Literature, Faculty of Foreign Languages, University of Isfahan, Isfahan, Iran \\ E-mail: dabaghi@fgn.ui.ac.ir \\ Ahmad Moinzadeh \\ Department of English Literature, Faculty of Foreign Languages, University of Isfahan, Isfahan, Iran \\ E-mail: moin@fgn.ui.ac.ir \\ Majid Mobasheri \\ Department of English Literature, Faculty of Foreign Languages, University of Isfahan, Isfahan, Iran \\ E-mail: majidm@gmail.com
}

\author{
Received: 03-03- 2015 \\ Accepted: 31-05- 2015 \\ Advance Access Published: August 2015 \\ Published: 01-11- 2015 \\ doi:10.7575/aiac.ijalel.v.4n.6p.1 \\ URL: http://dx.doi.org/10.7575/aiac.ijalel.v.4n.6p.1
}

\begin{abstract}
This descriptive study attempts to see to what extent interpreter training courses offered in bachelor's degree of English translation in Iranian universities are able to prepare students by teaching them the necessary skills of interpreting. Semi-structured interviews with experts and review of literature were used to find the skills required in interpreter training. A researcher made questionnaire, containing 69 items with a four point Likert scale was made to find out how much the students felt they had learned each necessary skill during their courses. A total of 103 students from six different universities completed the questionnaire. SPSS 17 was used to the analysis the data. The data gathered revealed that $67 \%$ of the students received a mean score of less than half the highest possible score. There was a significant difference between the six universities $(\mathrm{P}<0.001)$. The results of this study can be used by curriculum planners in the reformation and improvement of interpreter training courses.

Keywords: interpreter training; simultaneous interpreting; consecutive interpreting; curriculum evaluation

\section{Introduction}

While translation and interpreting can be both defined as professions used to ease communication between people, they are in essence different in nature. Time is the most obvious difference between these two professions. Interpreters need to be trained in order to be able to overcome the disadvantages that they face over a translator (Mahmoudzadeh, 2010a). Training course for interpreters should include core interpreting subjects and interpreting-related subjects. Also, inadequate courses may be counter-productive as they give the students the false impression that they know everything only to realize they have yet a lot to learn (Mahmoudzadeh, 2010b)

Ideally, a separate major should be taught for interpreting in universities. Many colleges and universities provide such courses around the world such as University of Geneva, Georgetown University and many more. Most researches carried out in this field have compared universities with market demands (Gile, 1990; Kurz, 1989; Mardani, 2013; Moser-Mercer, 1994; Pym, 2011; Yazdanparast, 2012). However, these researches have not evaluated interpreter training courses on their own and no research has been carried out in Iran to evaluate the courses offered to the students. In a study carried out by Moser-Mercer et al. (2005), students' satisfaction of interpreter trainer certification course was evaluated. This course was offered to interpreter trainers as nine months of distance learning along with one week of face-to-face learning. This study, however, has looked at the learning environment and the tools of the course offered; and has briefly asked the participants whether they have acquired skills for the training of students or not. That is to say, it has not gone into the details of what skills and to what extent these skills have been taught. The results of their study showed that "...the Certificate course provides for a learning experience which is almost always professionally relevant... Students expect their online learning almost always (...) to be interesting and directly related to their professional practice; and they perceive that this occurs very often.” (Moser-Mercer, 2005, p.16)

Different scholars have different definitions of what a curriculum is and what it should entail. For the purposes of this paper, the view of scholars such as Kaufman and Tanner will be mentioned briefly. Tanner and Tanner (1975, p.45) defined curriculum as "a plan that describes the necessary and insufficient 'means' for achieving particular learning "ends." Kaufman (1983, p.54) also stated that "curriculum is a means to an end. It should be judged as a means and changed accordingly." Lim (2006, p.217) believes that before any evaluation is to take place, first a needs assessment needs to be carried out. That is, the 'ends' and final goal mentioned in the previous definitions need to be figured out in order to see whether the current curriculum meet those needs or not. This study looks at the final goal as the students' knowledge in the skills and techniques required for interpreting.
\end{abstract}




\section{Methodology}

The study is descriptive in nature and aims to evaluate the interpreter training courses presented in universities of Iran to bachelor's students of English translation based on the students' point of view on how much they have learned. Therefore, the population of the study was all bachelor students of English Translation. The selected sample for this study was 103 students from 6 different universities. The following research question was formulated in order to see whether interpreter training courses are adequate or not:

1) To what extent have the students of Bachelor degree of English Translating in Iranian Universities been familiarized with the basic definitions and concepts of interpreting and the skills and techniques related to simultaneous and consecutive interpreting in the 'interpreting' course?

2) Is there a statistical difference between the six universities in this study in terms of the skills and techniques taught to the students for interpreting as indicated in the previous question?

The descriptive nature of the first question means that no hypothesis is needed. However, as the second research questions aims to differentiate between the universities in this study, a hypothesis is required. Therefore, the following hypothesis has been formulated:

Hypothesis: There is a no significant statistical difference between the six universities in terms of the skills and techniques taught to the students during the interpreting course.

A researcher-developed questionnaire was prepared for the gathering of the data. The questionnaire consisted of two main parts. The first section was designed to gather general and demographic information about the participants. This section of the questionnaire consisted of six questions such as gender, mother-tongue etc. The second part collected data regarding the student's knowledge and the training they received during their course.

The second section of the questionnaire was divided into three parts consisting of 69 items. The first part, "basic definitions", contains six items related to different types of interpreting and their meaning. The second part, containing 40 items, is titled "techniques for consecutive interpreting". These 40 items include topics such as the three necessary stages of consecutive interpreting, note-taking and memory skills. The final part, "techniques for simultaneous interpreting", with 23 items, includes topic such as the ability to use the equipment properly, developing split attention, methods of reformulation and timing.

The students had to answer each of these items by selecting one option on a four point Likert scale. The values for the scale are:

Hasn't been taught: 1, Mentioned briefly: 2, Has been taught: 3 and Thoroughly explained: 4 .

The content validity of the questionnaire was checked by experts' opinions. Test-retest was carried out on 15 subjects to check the reliability of the questionnaire and Cronbach's alpha was calculated to be 0.8 .

SPSS 17 software was used for data analysis. Other than simple methods of descriptive data analysis, such as frequency and mean, non-parametric independent sample was used to analyse the data because the data were not normally distributed. The Kruskal-Wallis $\mathrm{H}$ test was used to see if there is a significant difference between the universities or not. A P value of less than 0.001 was considered as a significant difference.

\section{Results}

A total of 103 students of English translating from six universities took part in this study, out which 26 were from Allame Tabatabaie University, 20 from Sheikh Bahaee University, 19 from University of Shahrekord, 14 from University of Isfahan, 12 from Khorasgan Azad University and 12 from the Isfahan branch of Payame Noor. Of these students, $32(31.1 \%)$ were male and $71(68.9 \%)$ were female. Table 1 shows the distribution of the answers given by all of the participants in this study. Each item has been shown separately in Table 1 (see Appendix 1).

3.1 Overall Score of the Universities

Having shown the data gathered from all of the subjects, this section will show whether and to what extent the score each university obtained in the questionnaire differed from each other. By giving a score to each item in the Likert scale and as explained in the methodology, the score for each university was calculated and is provided in Table 2 below. It should be noted, however, that this will be the total score obtained for the entire questionnaire and not just one section.

\begin{tabular}{llllll}
\multicolumn{5}{l}{ Table 1. Sum Score and Mean of Each University for the Whole Questionnaire (questions 1 to 69) } \\
\hline University & Minimum & Maximum & Mean & $\begin{array}{l}\text { Standard } \\
\text { Deviation }\end{array}$ & $\mathrm{P}$ \\
\hline University of Isfahan & 71 & 95 & 83.8 & 7.8 & $\mathrm{P}<0.001$ \\
Allame Tabatabaie University & 115 & 240 & 179.2 & 34.6 & \\
University of Shahrekord & 72 & 155 & 98.9 & 21.7 & \\
Sheikh Bahaee University & 101 & 253 & 195.3 & 43.3 & \\
Khorasgan Azad University & 71 & 167 & 117.1 & 34.7 & \\
Payame Noor Isfahan & 87 & 144 & 106.3 & 18.4 & \\
Total & 71 & 253 & 138.8 & 53.2 & \\
\hline
\end{tabular}

The Kruskal-Wallis $\mathrm{H}$ test showed that there is a significant difference between the universities $(\mathrm{P}<0.001)$. Given that there are 69 questions in the questionnaire, the lowest possible score is 69 and the highest possible score is 276 . The 
results in Table 2 show that Sheikh Bahaee University managed to get the highest mean score (195.3) among these six universities. University of Isfahan also received the lowest mean score (83.8).

\section{Discussion and Conclusion}

In the previous section, Table 1 showed the distribution of the answers given by all of the 103 students. A quick look at the table shows that the majority of the students felt that they had not learned the basic definitions and concepts of interpreting (questions one to six). The second and third section of the questionnaire is also in similar conditions. The majority of the students in each item in the questionnaire have said that these skills and techniques have either not been taught or only mentioned briefly. Before looking at the possible reasons for these results, the second research question and its hypothesis need to be talked about.

As only the second research question had a hypothesis, the hypothesis will be presented here again and a brief explanation will be given based on the obtained results shown in the previous sections.

Hypothesis: There is a no significant statistical difference between the six universities in terms of the skills and techniques taught to the students during the interpreting course.

As explained in the previous sections, there was in fact a significant difference between the universities in each section. The Kruskal Wallis-H test was also used to see if there is a significant difference between the universities in the overall score they each achieved. Table 2 showed that there is a significant difference between the universities $(\mathrm{P}<0.001)$, disproving the aforementioned hypothesis.

The implications of this study have more of an effect on the practical side of interpreter training than on the theoretical aspects of interpreting in general. The following paragraphs talk about the possible causes of these scores and will attempt to give some suggestions to curriculum planners and interpreter trainers on how to improve the courses presented in Iranian universities.

Different factors can be considered to be the cause of the differences between the universities in this study. The most obvious of these factors, is in fact, the teachers of these courses. Interviews with the Sheikh Bahaee University and Allame Tabatabaie University teachers revealed that they were in fact, researchers and experts in the field of interpreting. However, teachers in the other four universities had majored in English Teaching and either had not learned anything related to the subject or were not interested in this field.

It should also be pointed out here again, that the University of Isfahan offers interpreter training as a single, 2 unit course and not as three, 2 unit courses. This can greatly affect the learning outcome of the students as the teacher does not have enough time to teach all the important skills.

As most of these courses are either held in normal classroom or in laboratories (the equipment of which are never used), the students never get the opportunity to talk in a conference like situation and therefore do not pay attention to the communication skills which is required of them as a speaker and not just an interpreter.

A lack of resources available also makes the teaching methods harder. Currently there is no text book available to the students and the teachers, which they can use as a point of reference in learning the necessary skills. However, it should be pointed out that resources, does not refer to only text books. Most of the interpreting work done by students is done by translating what their teacher or classmates say. Videos and audio files of native speakers are rarely used during these classes.

Due to the short amount of time the teacher has, many essential skills, for example in note-taking, are often neglected. The skills for note-taking require much practice and they need to be explained thoroughly to the students. The students must become so skilled in note-taking, that they are able to make notes for speech segments of five minutes and read them back to the class.

The same argument can be made about other aspects of teaching consecutive interpreting. Memory training, for example, is a skill which needs to be improved over a period of time.

The equipment a simultaneous interpreter requires, although not hard to find, are rarely ever used during the course. Even though most universities have laboratories, most of their equipment is either out of date or not suitable for teaching simultaneous interpreters. One may argue that the basic use of headphones and microphones are rudimentary and simple explanations will suffice and working in a booth is no different than working outside the booth. However, all scholars and experienced interpreters believe that in order to overcome nerves and gain first-hand experience, practice with this equipment is essential during training.

The implications of this study have more of an effect on the practical side of interpreter training than on the theoretical aspects of interpreting in general. Curriculum planners and interpreter trainers can use the data shown in this study to improve the training courses provided in Iranian universities.

Based on the issues mentioned in this section, a few suggestions will be made on how to improve interpreter training courses. The first issue that needs to be dealt with is the selection of the trainers. As explained before, the majority of trainers are not familiar with the basic concepts of translation, let alone interpreting. Training the trainers is fastest way to improve the teaching standards of interpreter training courses.

The next step, which can be seen to be just as important as the previous, is the preparation of resources. This step may include preparation of textbooks, audio and video files and homework material. There are quite a few textbooks written for aspiring interpreters; unfortunately none of these were used in the universities in this study. These books can be 
either brought in to be used in the interpreter training courses or used as points of reference in writing a new textbook by scholars and experts in Iran.

The use of audio and video files also needs to be carefully planned by experts in the field. Although there is an abundance of audio and video files on the internet, these material need to be selected carefully to meet the students' needs.

Although most universities have laboratories equipped with headphones and cubicles, they are rarely ever use during the course of interpreter training. Four out of the six universities investigated in this study, did not use the laboratories and the two that did use them, did not teach the students how to use the equipment. It should also be pointed out that the cubicles in laboratories are not suitable to be used for simultaneous interpreting, as simultaneous interpreting needs to be done in sound proof booths.

The last, but in no way least important, issue that needs to be addressed is the duration of the training course. As previously explained University of Isfahan offered this course as a single 2 unit course and also received the lowest average score. Even if all the suggestions made above are implemented in the training courses, there needs to be enough time for practice during these courses. Having three 2 unit courses, as the majority of universities do, does help to increase the learning standards greatly. However, it is strongly advised that Iranian universities look at interpreting as a separate major completely and offer interpreter training as a four year undergraduate course.

This is also in concurrence of previous research carried out by Mahmoudzadeh, who has shown that university training does not meet market demands (Mahmoudzadeh, 2010c; Mahmoudzadeh, 2010d).

\section{References}

Gile, D. (1990). Scientific Research vs. Personal Theories in the Investigation of Interpretation. In Aspects of Applied and Experimental Research on Conference Interpretation. Ed. by L. Gran \& C. Taylor, p. 28-41. Udine: Campanotto.

Lim, H. (2006). A Comparison of Curricula of Graduate Schools of Interpretation and Translation in Korea. Meta : journal des traducteurs / Meta. Translators' Journal, 51(2), 215-228.

Kaufman, R. A. (1983). Needs Assessment. In F. W. English, Fundamental Curriculum Decisions: 1983 ASCD Yearbook. Alexandria: Jarboe.

Kurz, I. (1989). The Use of Video-Tapes in Consecutive and Simultaneous Interpretation Training. In The Theoretical and Practical Aspects of Teaching Conference Interpretation. Ed. by L. Gran \& J. Dodds, p. 213-215. Udine: Campanotto.

Mahmoudzadeh, K. (2010). Time: the Major Difference between Translating and Interpreting. A Collection of Papers on Interpreting and Bilingualism, pp. 40-49.

Mahmoudzadeh, K. (2010). Factors Determining the Success of an Interpreter and His Performance. A Collection of Papers on Interpreting and Bilingualism, pp. 130-139.

Mahmoudzadeh, K. (2010). Bilingualism and Teaching Interpreting. A Collection of Papers in Interpreting and Bilingualism, pp. 79-86.

Mahmoudzadeh, K. (2010). Why Do You Have to Mumble? A Glance at the Performance of Interpreters. A Collection of Papers on Interpreting and Bilingualism, pp. 50-60.

Mardani, F. B. (2013). Translation Agencies in Iran: A Brief Investigation of the Recruitment Criteria. Mediterranean Journal of Social Sciences, 4(2), 59.

Moser-Mercer, B. (1994). Paradigms Gained or the Art of Productive Disagreement. In Bridging the Gap: Empirical Research in Simultaneous Interpretation. Ed. by S. Lambert \& B. Moser-Mercer, pp. 17-23. Amsterdam-Philadelphia: Benjamins.

Moser-Mercer, B., Class, B., \& Seeber, K. (2005). Leveraging virtual learning environments for training interpreter trainers. Meta: Journal Des Traducteurs, 50(4). doi:10.7202/019872ar

Tanner, D. a. (1975). Curriculum Development: Theory into Practice. New York: Macmillan.

Pym, A. (2011). Training Translators. In K. Malmkjaer \& K. Windle (Eds.), The Oxford Handbook of Translation Studies (pp. 475-489). Oxford: Oxford University Press.

Yazdanparast, M. (2012). A Study on the Courses for MA Translation Students in Iran : Are Graduate Students Welcome by the Market? Master's thesis. Isfahan, Iran: University of Isfahan. 
Table 2. Distribution of the Answers Given by the Students

\begin{tabular}{|c|c|c|c|c|}
\hline Basic Definition & 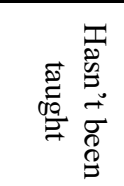 & 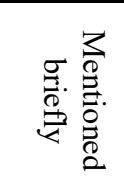 & 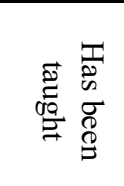 & 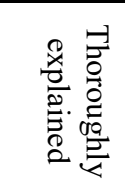 \\
\hline $\begin{array}{l}\text { 1) As a general rule, an interpreted text should take three quarters of } \\
\text { the time taken by the original. }\end{array}$ & $\begin{array}{r}34 \\
(33 \%)\end{array}$ & $\begin{array}{r}29 \\
(28.2 \%)\end{array}$ & $\begin{array}{r}24 \\
(23.3 \%)\end{array}$ & $\begin{array}{r}16 \\
(15.5 \%)\end{array}$ \\
\hline 2) Whispered (so-called 'chuchotage') has been defined. & $\begin{array}{r}63 \\
(61.2 \%)\end{array}$ & $\begin{array}{r}15 \\
(14.6 \%)\end{array}$ & $\begin{array}{r}18 \\
(17.5 \%)\end{array}$ & $\begin{array}{r}7 \\
(6.8 \%)\end{array}$ \\
\hline 3) The definition of passive language has been given. & $\begin{array}{r}52 \\
(50.5 \%)\end{array}$ & $\begin{array}{r}23 \\
(22.3 \%)\end{array}$ & $\begin{array}{r}19 \\
(18.4 \%)\end{array}$ & $\begin{array}{r}9 \\
(8.7 \%)\end{array}$ \\
\hline 4) Active language has been explained. & $\begin{array}{r}75 \\
(72.8 \%)\end{array}$ & $\begin{array}{r}25 \\
(24.3 \%)\end{array}$ & $\begin{array}{r}26 \\
(25.2 \%)\end{array}$ & $\begin{array}{r}5 \\
(4.9 \%)\end{array}$ \\
\hline 5) Retour in interpreting has been defined. & $\begin{array}{r}75 \\
(72.8 \%)\end{array}$ & $\begin{array}{r}11 \\
(10.7 \%)\end{array}$ & $\begin{array}{r}12 \\
(11.7 \%)\end{array}$ & $\begin{array}{r}5 \\
(4.9 \%)\end{array}$ \\
\hline 6) Working in Relay has been described. & $\begin{array}{r}63 \\
(61.2 \%)\end{array}$ & $\begin{array}{r}18 \\
(17.5 \%)\end{array}$ & $\begin{array}{r}15 \\
(14.6 \%)\end{array}$ & $\begin{array}{r}7 \\
(6.8 \%)\end{array}$ \\
\hline
\end{tabular}

\section{Techniques for Consecutive interpreting}

7) The three basic stages of consecutive interpreting have been talked about.

8) The first stage, understanding, has been clarified.

9) The difference between linguistic understanding and understanding of ideas has been described.

10) Different techniques of dealing with a word or phrase you are unfamiliar with have been given.

11) When faced with an unfamiliar word, you are allowed to not translate it, if it is not essential to the message.

12) The extent to which asking for clarification from the speaker if you do not understand something has been explained.

13) Active listening has been practiced during the course.

14) Methods of how to recognize different speech types in analysis of speech type, the second stage in consecutive interpreting, have been given.

15) The interpreter is allowed to tone down comments, for example, in cases where the repetition of a tactless or rude remark will not benefit the speaker or the meeting in general.

16) The tactics of how to deal with references, especially people's titles, have been made clear.

17) In the translation of metaphors and similes, the amounts in which the interpreter may deviate from the original have been explained during the course.

18) Identification of main ideas was practiced.

19) It was shown during the class, how an interpreter may select some ideas in order to delete some elements when under pressure.

20) The ability to recognize epithets and adverbs, and when you are allowed to omit them, was taught.

20) The ability to recognize epithets and adverbs, and when you are allowed to omit them, was taught.

\begin{tabular}{rrrr}
40 & 23 & 19 & 21 \\
$(38.8 \%)$ & $(22.3 \%)$ & $(18.4 \%)$ & $(20.4 \%)$ \\
17 & 33 & 27 & 26 \\
$(16.5 \%)$ & $(32 \%)$ & $(26.2 \%)$ & $(25.2 \%)$ \\
48 & 19 & 24 & 12 \\
$(46.6 \%)$ & $(18.4 \%)$ & $(23.3 \%)$ & $(11.7 \%)$ \\
16 & 36 & 18 & 33 \\
$(15.5 \%)$ & $(35 \%)$ & $(17.5 \%)$ & $(32 \%)$ \\
29 & 32 & 18 & 24 \\
$(28.2 \%)$ & $(31.1 \%)$ & $(17.5 \%)$ & $(23.3 \%)$ \\
& & & \\
44 & 33 & 13 & 13 \\
$(42.7 \%)$ & $(32 \%)$ & $(12.6 \%)$ & $(12.6 \%)$ \\
23 & 31 & 23 & 26 \\
$(22.3 \%)$ & $(30.1 \%)$ & $(22.3 \%)$ & $(25.2 \%)$ \\
47 & 25 & 24 & 7 \\
$(45.6 \%)$ & $(24.3 \%)$ & $(23.3 \%)$ & $(6.8 \%)$ \\
& & & \\
21 & 43 & 24 & 15 \\
$(20.4 \%)$ & $(41.7 \%)$ & $(23.3 \%)$ & $(14.6 \%)$ \\
& & & \\
46 & 29 & 17 & 11 \\
$(44.7 \%)$ & $(28.2 \%)$ & $(16.5 \%)$ & $(10.7 \%)$ \\
29 & 44 & 22 & 8 \\
$(28.2 \%)$ & $(42.7 \%)$ & $(21.4 \%)$ & $(7.8 \%)$ \\
& & & \\
25 & 27 & 32 & 19 \\
$(24.3 \%)$ & $(26.2 \%)$ & $(31.1 \%)$ & $(18.4 \%)$ \\
24 & 37 & 22 & 20 \\
$(23.3 \%)$ & $(35.9 \%)$ & $(21.4 \%)$ & $(19.4 \%)$ \\
41 & 33 & 21 & 8 \\
$(39.8 \%)$ & $(32 \%)$ & $(20.4 \%)$ & $(7.8 \%)$ \\
75 & 15 & 9 & 4 \\
$(72.8 \%)$ & $(14.6 \%)$ & $(8.7 \%)$ & $(3.9 \%)$ \\
\hline & & &
\end{tabular}


22) Different types of examples, whether they are for illustrative purposes and can be edited or they have intrinsic importance, have been shown.

23) The skill of being able to recognize and analyze links between ideas was taught.

24) Explanations regarding memory skills were given during the course.

25) Methods of using mnemonic techniques were demonstrated.

26) Visualizing techniques to help connect and remember ideas were carried out.

27) The importance of concluding remarks made at the end of a speech was clarified.

28) The third stage in consecutive interpreting, re-expression has been practiced in class.

29) The role of notes in consecutive interpreting (not an end themselves, but a means to an end) has been explained.

30) It has been explained as to why notes should not be merely shorthand of the words spoken by the speaker.

31) Reasons for using a note-pad and not loose sheet of paper have been given.

32) It was explained why when taking notes; both sides of a paper should not be used.

33) Methods of making up symbols were explained and reasons for not making ad-hoc symbols were given.

34) Notes are not a detailed account of ideas, but prompts on how to start and finish an idea.

35) Links and separations should appear in the notes.

36) In consecutive interpreting, upon hearing a number or date, the interpreter should stop everything else and note down the number or date.

37) The main ideas should be based around a subject-verb-object analysis.

38) When taking notes in English, it is better to separate each component, subject-verb-object, diagonally, working from left to right, from top to bottom.

39) Placing links on the extreme left hand margin is logical thing to do.

40) Separation of ideas can be shown by drawing a horizontal line.

41) Symbols used in notes represent ideas and not words.

42) If a symbol has been used properly, other symbols can be derived from it by using the same logic. (for example if '?' means demand, the reverse symbol can mean supply)

43) Different methods of showing verb tense in a sentence in your notes have been elaborated.

44) Stress in a sentence must be shown in your notes.

45) The reasons for choosing what language to take your notes in, target or source, have been talked about.

46) The question of when to start taking notes has been answered.
$(46.6 \%)$

$(25.2 \%)$

$(21.4 \%)$

(6.8\%)

$\begin{array}{rrrr}51 & 29 & 14 & 9 \\ (49.5 \%) & (28.2 \%) & (13.6 \%) & (8.7 \%) \\ 20 & 33 & 16 & 34 \\ (19.4 \%) & (32 \%) & (15.5 \%) & (33 \%) \\ 41 & 25 & 13 & 24 \\ (39.8 \%) & (24.3 \%) & (12.6 \%) & (23.3 \%) \\ 44 & 23 & 11 & 25 \\ (42.7 \%) & (22.3 \%) & (10.7 \%) & (24.3 \%) \\ 41 & 34 & 17 & 11 \\ (39.8 \%) & (33 \%) & (16.5 \%) & (10.7 \%) \\ 44 & 23 & 21 & 15 \\ (42.7 \%) & (22.3 \%) & (20.4 \%) & (14.6 \%) \\ 27 & 30 & 19 & 27 \\ (26.2 \%) & (29.1 \%) & (18.4 \%) & (26.2 \%) \\ 39 & 24 & 20 & 20 \\ (37.9 \%) & (23.3 \%) & (19.4 \%) & (19.4 \%) \\ 52 & 23 & 12 & 16 \\ (50.5 \%) & (22.3 \%) & (11.7 \%) & (15.5 \%) \\ 74 & 12 & 10 & 7 \\ (71.8 \%) & (11.7 \%) & (9.7 \%) & (6.8 \%) \\ 40 & 20 & 16 & 27 \\ (38.8 \%) & (19.4 \%) & (15.5 \%) & (26.2 \%) \\ 33 & 30 & 19 & 21 \\ (32 \%) & (29.1 \%) & (18.4) & (20.4 \%) \\ 50 & 23 & 18 & 12 \\ (48.5 \%) & (22.3 \%) & (17.5 \%) & (11.7 \%) \\ 48 & 21 & 19 & 15 \\ (46.6 \%) & (20.4 \%) & (18.4 \%) & (14.6 \%)\end{array}$

44

$(42.7 \%)$

$(24.3 \%)$

(21.4\%)

64

$(62.1 \%)$

(10.7\%)

(15.5\%)

71

$(68.9 \%)$

(15.5\%)

(10.7\%)

$(4.9 \%)$

66

(64.1\%)

56

(54.4\%)

49

$(47.6 \%)$

$(14.6 \%)$

17

(16.5\%)

26

(25.2\%)

13

(12.6\%)

(8.7\%)

17

(16.5\%)

(12.6\%)

17

(16.5\%)

(10.7\%)

57

$(55.3 \%)$

23

(22.3\%)

$(13.6 \%)$

$(8.7 \%)$

56

(54.4\%)

24

(23.3\%)

(12.6\%)

$(9.7 \%)$

51

(49.5\%)

$(16.5 \%)$

(18.4\%)

(15.5\%)

51

(49.5\%)

(17.5\%)

(18.4\%)

\%)

7

0

6

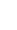

7


Techniques for Simultaneous Interpreting

47) The equipment which a simultaneous interpreter must use have been introduced.

48) Use of equipment, such as booth and headphones, has been practiced during the class.

49) The interpreter must be able to listen to the speaker and hear their own output in order to monitor themselves all the time.

50) Advantages of left ear to listen to the speaker, and right ear to monitor your own voice, have been mentioned during the course.

51) The level at which the volume of the headphones should be has been explained.

52) Methods of developing split attention have been practiced in class.

53) Shadowing has been explained.

54) When interpreting, it is best to speak in short, simple sentences composed of one principle clause.

55) Interpreters must never leave a sentence unfinished.

56) The notion of a unit of meaning has been explained.

57) The interpreter must start speaking as soon as they have enough material from the speaker to finish their own sentence.

58) The interpreter should try to end a speech as close as possible to the speaker.

59) Reformulation was practiced in class.

60) Multi-translations have been talked about and reasons for avoiding them have been given.

61) Situations where the colleague in the booth may and should help have been taught.

62) Different situations where you don't understand a word have been explained and solutions have been provided.

63) The Salami technique has been provided as an alternative to reformulation.

64) The situations in which interpreters may use gap fillers, such as well, so to speak, actually, ... to help themselves by providing them with more time have been talked about.

65) Simplification is another technique taught in the course.

66) Generalization, use of generic terms to refer to a number of specific items, was talked about.

67) Situations in which omission is allowed were elaborated.

68) Anticipation exercises were carried out in class.

69) The use of Pat phrases, used in order to save time and energy, have been introduced.

\begin{tabular}{|c|c|c|c|}
\hline $\begin{array}{r}50 \\
(48.5 \%)\end{array}$ & $\begin{array}{r}25 \\
(24.3 \%)\end{array}$ & $\begin{array}{r}9 \\
(8.7 \%)\end{array}$ & $\begin{array}{r}19 \\
(18.4 \%)\end{array}$ \\
\hline $\begin{array}{r}57 \\
(55.3 \%)\end{array}$ & $\begin{array}{r}21 \\
(20.4 \%)\end{array}$ & $\begin{array}{r}14 \\
(13.6 \%)\end{array}$ & $\begin{array}{r}11 \\
(10.7 \%)\end{array}$ \\
\hline $\begin{array}{r}42 \\
(40.8 \%)\end{array}$ & $\begin{array}{r}17 \\
(16.5 \%)\end{array}$ & $\begin{array}{r}23 \\
(22.3 \%)\end{array}$ & $\begin{array}{r}21 \\
(20.4 \%)\end{array}$ \\
\hline $\begin{array}{r}62 \\
(60.2 \%)\end{array}$ & $\begin{array}{r}22 \\
(21.4 \%)\end{array}$ & $\begin{array}{r}13 \\
(12.6 \%)\end{array}$ & $(5.8 \%)$ \\
\hline 43 & 31 & 18 & 11 \\
\hline$(41.7 \%)$ & $(30.1 \%)$ & $(17.5 \%)$ & $(10.7 \%)$ \\
\hline 56 & 14 & 16 & 17 \\
\hline $54.4 \%)$ & $(13.6 \%)$ & $(15.5 \%)$ & (16.5) \\
\hline 50 & 9 & 6 & 38 \\
\hline $48.5 \%)$ & $(8.7 \%)$ & $(5.8 \%)$ & $(36.9 \%)$ \\
\hline $\begin{array}{r}30 \\
(29.1 \%)\end{array}$ & $\begin{array}{r}36 \\
(35 \%)\end{array}$ & $\begin{array}{r}14 \\
(13.6 \%)\end{array}$ & $\begin{array}{r}23 \\
(22.3 \%)\end{array}$ \\
\hline $\begin{array}{r}31 \\
0.1 \%)\end{array}$ & $\begin{array}{r}28 \\
27.2 \%)\end{array}$ & $\begin{array}{r}22 \\
(21.4 \%)\end{array}$ & $\begin{array}{r}22 \\
(21.4 \%)\end{array}$ \\
\hline 44 & 25 & 16 & 18 \\
\hline $42.7 \%)$ & $(24.3 \%)$ & $(15.5 \%)$ & $(17.5 \%)$ \\
\hline 45 & 24 & 15 & 19 \\
\hline $43.7 \%)$ & $(23.3 \%)$ & $(14.6 \%)$ & $(18.4 \%)$ \\
\hline 46 & 27 & 13 & 17 \\
\hline$(44.7 \%)$ & $(26.2 \%)$ & $(12.6 \%)$ & $(16.5 \%)$ \\
\hline $\begin{array}{r}57 \\
(55.3 \%)\end{array}$ & $\begin{array}{r}23 \\
(22.3 \%)\end{array}$ & $\begin{array}{r}12 \\
(11.7 \%)\end{array}$ & $\begin{array}{r}11 \\
(10.7 \%)\end{array}$ \\
\hline $\begin{array}{r}60 \\
(58.3 \%)\end{array}$ & $\begin{array}{r}23 \\
(22.3 \%)\end{array}$ & $\begin{array}{r}14 \\
(13.6 \%)\end{array}$ & $\begin{array}{r}6 \\
(5.8 \%)\end{array}$ \\
\hline $\begin{array}{r}62 \\
(60.2 \%)\end{array}$ & $\begin{array}{r}20 \\
(19.4 \%)\end{array}$ & $\begin{array}{r}12 \\
(11.7 \%)\end{array}$ & $\begin{array}{r}9 \\
(8.7 \%)\end{array}$ \\
\hline $\begin{array}{r}42 \\
(40.8 \%)\end{array}$ & $\begin{array}{r}23 \\
(22.3 \%)\end{array}$ & $\begin{array}{r}16 \\
(15.5 \%)\end{array}$ & $\begin{array}{r}22 \\
(21.4 \%)\end{array}$ \\
\hline $\begin{array}{r}79 \\
76.7 \%)\end{array}$ & $\begin{array}{r}17 \\
(16.5 \%)\end{array}$ & $\begin{array}{r}6 \\
(5.8 \%)\end{array}$ & $\begin{array}{r}1 \\
(1 \%)\end{array}$ \\
\hline $\begin{array}{r}49 \\
(47.6 \%)\end{array}$ & $\begin{array}{r}16 \\
(15.5 \%)\end{array}$ & $\begin{array}{r}25 \\
(24.3 \%)\end{array}$ & $\begin{array}{r}13 \\
(12.6 \%)\end{array}$ \\
\hline $\begin{array}{r}41 \\
(39.8 \%)\end{array}$ & $\begin{array}{r}23 \\
(22.3 \%)\end{array}$ & $\begin{array}{r}24 \\
(23.3 \%)\end{array}$ & $\begin{array}{r}15 \\
(14.6 \%)\end{array}$ \\
\hline $\begin{array}{r}30 \\
(29.1 \%)\end{array}$ & $\begin{array}{r}30 \\
(29.1 \%)\end{array}$ & $\begin{array}{r}21 \\
(20.4 \%)\end{array}$ & $\begin{array}{r}22 \\
(21.4 \%)\end{array}$ \\
\hline $\begin{array}{r}41 \\
(39.8 \%)\end{array}$ & $\begin{array}{r}24 \\
(23.3 \%)\end{array}$ & $\begin{array}{r}15 \\
(14.6 \%)\end{array}$ & $\begin{array}{r}23 \\
(22.3 \%)\end{array}$ \\
\hline 45 & 17 & 17 & 24 \\
\hline$(43.7 \%)$ & $(16.5 \%)$ & $(16.5 \%)$ & $(23.3 \%)$ \\
\hline $\begin{array}{r}65 \\
53.1 \%)\end{array}$ & $\begin{array}{r}22 \\
(21.4 \%)\end{array}$ & $\begin{array}{r}11 \\
(10.7 \%)\end{array}$ & $\begin{array}{r}5 \\
(4.9 \%)\end{array}$ \\
\hline
\end{tabular}

